\title{
DAYA REPELAN LOTION MINYAK KETAPANG PADA BERBAGAI VARIASI KONSENTRASI ATSIRI KULIT JERUK PURUT
}

\section{REPELLANCY OF THE LOTION KETAPANG CERNEL OIL WITH VARIATION CONCENTRATION KAFFIR LIME PEEL ESSENTIAL OIL}

\author{
Sri Seno Handayani, Erin Ryantin Gunawan, Dedy Suhendra, Murniati, dan Rizka Dhia Khalilah Bali \\ Program Studi Kimia FMIPA Universitas Mataram, Mataram, Indonesia \\ e-mail: srihandayani@unram.ac.id
}

Diterima: 22 November 2020. Disetujui: 8 Februari 2021. Dipublikasikan: 3 Maret 2021

\begin{abstract}
Abstrak: Telah dilakukan penelitian lotion minyak ketapang dengan zat aktif tambahan minyak atsiri dari kulit jeruk purut sebagai anti nyamuk. Losion anti nyamuk yang tersedia di pasaran saat ini menggunakan bahan kimia sebagai bahan utama yang dapat menyebabkan resistensi terhadap nyamuk dan sangat berbahaya bagi kulit. Penelitian ini bertujuan untuk mengetahui uji tolak nyamuk losion minyak inti ketapang dengan penambahan variasi konsentrasi minyak atsiri kulit jeruk purut. Semua uji sifat fisik memenuhi kriteria sediaan lotion. $\mathrm{pH}$ dan daya sebar lotion diuji lagi setelah disimpan selama satu bulan. Berdasarkan hasil evaluasi diperoleh bahwa formula I, II dan III stabil secara fisik selama satu bulan penyimpanan dengan $\mathrm{pH}$ berkisar antara 6,7-7,0. pH lotion tidak mengalami perbedaan bermakna dibandingkan dengan ketika baru dibuat, sedangkan daya sebarnya mengalami perubahan setelah disimpan satu bulan. Daya repelan tertinggi dimiliki oleh lotion dengan konsentrasi minyak atsiri 3\%. Daya repelan lotion dapat bertahan selama 3 jam, setelah lebih dari 3 jam, efektifitas daya repelan lotion berkurang.
\end{abstract}

Kata kunci: Repelan, lotion, ketapang, jeruk purut

\begin{abstract}
Research on lotion ketapang cernel oil with additive active essential oil from kaffir lime peel as reppelant has been done. Mosquito repellent lotions available on the market today used of chemicals as the main ingredient can causing resistance to mosquitoes and the very harmful to the skin. This study aims to know of reppelant test of lotion ketapang cernel oil with variation concentration kaffir lime peel essential oil. These dosage formulations were prepared in three formulas using $10 \%$ ketapang cernel oil. Concentration of essential oil added is $0,0 \% ; 1,0 \% ; 2,0 \%$; and $3 \%$. Physical evaluation included organoleptic examination, $\mathrm{pH}$ and homogeneity. All tests of physical properties were fullfilled the criteria lotion preparations. Then the $\mathrm{pH}$ and spreadibility tested again after being stored for 1 month. Based on the results of the evaluation, it was found that the I, II and III formulations were physically stable for 1 month of storage with a $\mathrm{pH}$ ranging from 6.7 to $7.0 \mathrm{pH}$ of lotion not experience significant differences compared to when newly created, while the spreadibility changed after being stored 1 month. The highest repellant power is possessed by lotion ketapang cernel oil with an essential oil concentration of $3 \%$. The repellant of lotion can last for 3 hours, after more than 3 hours then the effectiveness of lotion repellant power will be reduced.
\end{abstract}

Keywords: Reppelant, lotion, ketapang, kaffir lime

\section{PENDAHULUAN}

Nyamuk merupakan serangga pengganggu yang dapat menularkan berbagai macam penyakit berbahaya bahkan dapat menyebabkan kematian bagi manusia. Penyakit yang disebabkan oleh nyamuk antara lain malaria, Demam Berdarah Dengue (DBD), cikungunya dan zika. Perlindungan secara individu menggunakan tolak nyamuk atau repelan merupakan antisipasi dini untuk mencegah gigitan nyamuk. Saat ini sebagian besar obat tolak nyamuk atau repelan yang beredar dipasaran mengandung bahan kimia sebagai bahan aktif. Repelan berfungsi untuk mengurangi kontak antara nyamuk dengan manusia. Repelan yang umum digunakan adalah repelan sintetis DEET (N,Ndiethyl-3-methyl toluamide) [7]. DEET merupakan repelan sintetis yang mampu menolak nyamuk, tetapi tidak aman untuk penggunaan jangka panjang.
DEET mudah diserap melalui kulit dan masuk ke dalam aliran darah sehingga mempengaruhi sistem saraf [13]. Repelan alami telah menjadi alternatif yang menjanjikan, selain tidak berbahaya untuk lingkungan repelan alami juga tidak mempengaruhi kesehatan manusia. Menurut [11] penggunaan repelan kimia tidak hanya membahayakan kesehatan manusia, tetapi juga dapat menyebabkan resistensi terhadap nyamuk itu sendiri. Indonesia merupakan negara yang memiliki potensi tanaman lokal yang mengandung insektisida alami yang tidak disukai oleh nyamuk. Minyak atsiri dari beberapa tumbuhan telah diuji dan memiliki potensi untuk menjadi repelan alami, salah satunya adalah jeruk purut. Minyak atsiri kulit buah jeruk purut hasil penyulingan uap ranting, daun, dan kulit buah tersusun atas 29 senyawa dengan komponen utama 
sitronelal mencapai 46,85-80,4\%. Kualitas kandungan minyak atsiri pada tanaman jeruk berdasarkan kadar limonene sangat dipengaruhi oleh pre-treatment [6]. Minyak atsiri kulit buah jeruk purut mengandung beberapa komponen utama seperti $\beta$-pinene $(21,44 \%)$, sitronelal $(20,91 \%)$, limonene $(12,59 \%)$, dan terpinen-4-ol $(11,93 \%)$ [14].

Hasil penelitian [8] senyawa citronella yang terdapat dalam minyak atsiri kulit buah jeruk purut dapat menjadi antirayap. Sedangkan [5] menyatakan bahwa senyawa linalool, sitronelol, dan geraniol memiliki aktifitas repelan terhadap beberapa arthropoda. Senyawa linalool merupakan racun bagi beberapa jenis serangga. [4] berhasil membuktikan bahwa senyawa-senyawa monoterpene pinen, cineol, eugenol, limonene, citronellol, citronellal, camphor dan timol memiliki efek repelan terhadap nyamuk.

Repelan alami dari tumbuhan biasanya dimanfaatkan dengan mengambil minyak atsiri tumbuhan tersebut. Namun penggunaan minyak atsiri sebagai penolak nyamuk secara langsung kurang efektif karena sifat minyak yang mudah menguap, maka perlu dibuat dalam bentuk sediaan yang sesuai agar lebih mudah dipakai dan menempel pada kulit sehingga memberikan daya tolak nyamuk yang lebih tahan lama. Salah satu cara adalah dengan membuat sediaan repelan dalam bentuk lotion yang berbasis emulsi minyak dalam air atau air dalam minyak dengan menggunakan emulgator untuk membentuk emulsi yang baik. Produk-produk lotion yang beredar dipasaran hingga saat ini masih menggunakan minyak mineral (white oil) yang merupakan bahan yang tidak dapat diperbaharui sebagai bahan utama untuk fase minyak. Minyak mineral atau parafin cair adalah hasil produk samping dari pengolahan minyak bumi untuk bahan bakar. Eksplorasi bahan baku kosmetik dan farmasi yang murah dan aman bagi kesehatan sangat diperlukan mengingat sampai saat ini bahan baku yang digunakan masih mengandalkan minyak pangan dan mahal seperti VCO, minyak zaitun dan lain-lain [12]. Minyak ketapang merupakan salah satu alternatif untuk menggantikan fungsi paraffin cair pada sediaan lotion.

Ketapang (Terminalia catappa L.) adalah nama sejenis pohon yang biasanya tumbuh alami di tepi pantai. Tanaman ini merupakan tumbuhan multiguna. Kayunya digunakan untuk . konstruksi rumah, bahan obat, dan bahkan sekarang banyak ditanam dipinggir jalan. Biji ketapang dapat menghasilkan minyak dengan kadar tinggi, yaitu 54,4\%. Minyak biji ketapang dapat diperoleh melalui proses ekstraksi. [1] menyatakan kualitas minyak ketapang tidak hanya dipengaruhi oleh jenis pelarut dan suhu ekstraksi, tetapi juga lamanya waktu ekstraksi. Minyak ketapang mengandung asam-asam lemak jenuh dan tak jenuh dengan jumlah yang cukup signifikan, yakni asam palmitat
$(35,63 \%)$, asam oleat $(33,49 \%)$, asam linoleat $(24,29 \%)$ dan asam stearat (4,66\%) [10]. Asamasam lemak tak jenuh dalam minyak ketapang dapat memberikan manfaat yang sangat baik bagi kulit. Keunggulan dari minyak ketapang ini dapat dimanfaatkan sebagai sebagai bahan utama lotion repelan.

Pemanfaatan minyak ketapang sebagai bahan utama lotion repelan memiliki beberapa keuntungan yaitu selain dapat menggantikan fungsi dari parafin cair, minyak ketapang berasal dari bahan yang dapat diperbarui yang memiliki kemampuan sebagai pelembut (emmolient). Menurut [3] minyak ketapang mengandung lemak total yang relatif tinggi $(58,90 \pm 0,71 \%)$ dibandingkan minyak kedelai, yaitu $20,59 \pm 0,72 \%$. Sedangkan menurut [2], asam oleat dan linoleat dapat menjaga kelembaban kulit dengan cara membentuk lapisan tipis diatas permukaan kulit sehingga akan mengurangi penguapan air dari kulit.

Tujuan dari penelitian ini adalah mengetahui daya repelan lotion minyak ketapang dengan penambahan atsiri kulit jeruk purut pada berbagai variasi. Uji organoleptik dan sifat fisik lotion dilakukan untuk mengetahui stabilitas lotion minyak ketapang.

\section{METODE PENELITIAN}

Alat-alat yang digunakan dalam penelitian ini adalah, rotary evaporator, alat soklet, alat refluks, alat shaker, magnetik stirer, alat destilasi uap, neraca analitik, dan GC-MS. Bahan-bahan penelitian adalah buah ketapang, buah jeruk purut, asam stearat, setil alkohol, paraffin cair, gliserin, metil paraben, TEA (trietanolamin), propil paraben, aseton, etanol, n-heksan, natrium sulfat anhidrat Penelitian ini terdiri dari beberapa tahap yaitu, tahap ekstraksi minyak ketapang, tahap ekstraksi minyak atsiri kulit jeruk purut, karakterisasi sifat fisiko kimia minyak ketapang, tahap formulasi lotion, tahap uji organoleptik dan sifat fisika kimia lotion dan tahap uji daya repelan lotion.

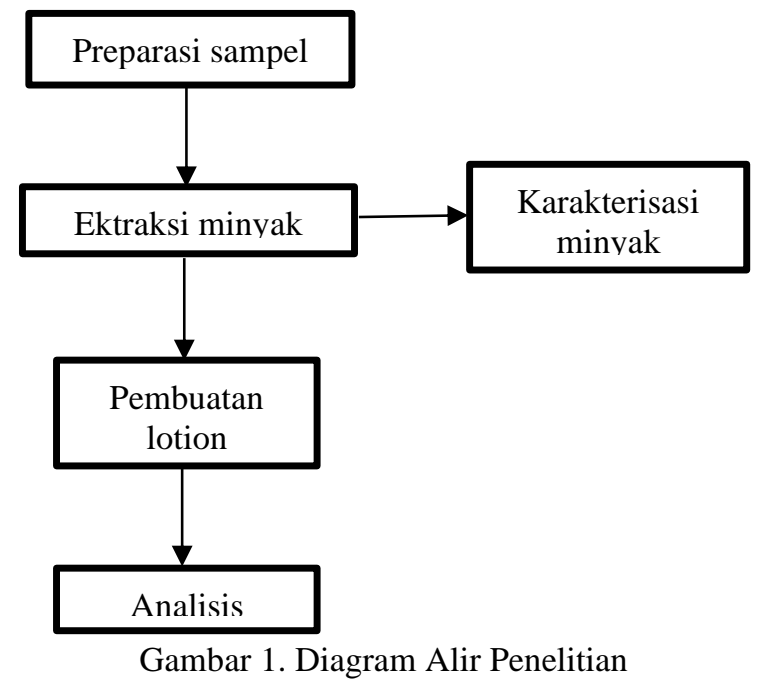




\section{Prosedur Penelitian}

Minyak inti buah ketapang diperoleh dengan menggunakan metode ekstraksi soxhletasi dengan pelarut n-heksan selama 6 jam diatas penangas air Minyak hasil ekstraksi kemudian dipisahkan dari pelarutnya menggunakan rotary evaporator pada suhu $40^{\circ} \mathrm{C}$. Sedangkan minyak atsiri kulit jeruk purut diperoleh melalui proses destilasi uap. Pada pembuatan repelan lotion bahan yang digunakan dibedakan menjadi dua golongan yaitu bahan yang larut dalam minyak (fase air) dan bahan yang larut dalam air (fase minyak). Bahan fase air yaitu air murni, gliserin, dan TEA. Sedangkan fase minyak yaitu setil alkohol, asam stearat dan minyak ketapang. Fase air dan fase minyak dipanaskan sambil diaduk pada suhu $70-75^{\circ} \mathrm{C}$ sampai homogen dan dilakukan secara terpisah. Kemudian kedua fase dicampur dan diaduk dengan stirrer hingga homogen. Kemudian dimasukkan minyak atsiri kulit jeruk purut dengan konsentrasi 0\%, 1\%, 2\% dan 3\% serta metil paraben dan diaduk. Pengadukan dilakukan sampai terbentuk emulsi yang stabil. Analisis yang dilakukan pada penelitian ini meliputi karakterisasi sifat fisiko kimia minyak ketapang yang terdiri dari bilangan asam, bilangan iod, bilangan penyabunan analisis uji organoleptik, $\mathrm{pH}$, homogenitas dan uji daya repelan lotion.

\section{HASIL DAN PEMBAHASAN \\ Ekstraksi Minyak}

Penelitian ini diawali dengan ekstraksi minyak ketapang dan isolasi minyak atsiri kulit jeruk purut. Berdasarkan hasil soxhletasi, diperoleh kadar minyak ketapang sebesar 58,7\%.

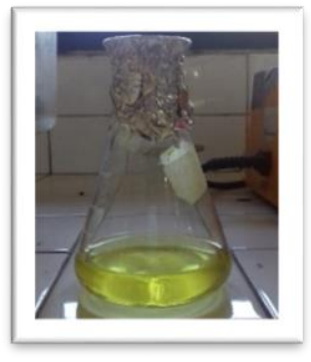

(a)

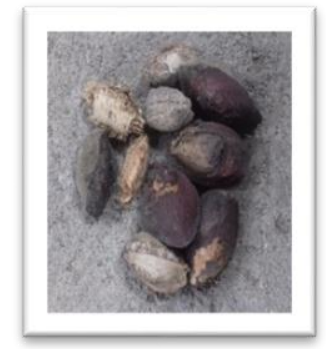

(b)
Gambar 2. (a) buah ketapang (b) minyak ketapang hasil ekstraksi

Hasil karakterisasi sifat fisiko kimia diperoleh bilangan asam dari minyak ketapang adalah 2,4 $\mathrm{mgNaOH} /$ gram dengan bilangan iod sebesar $92,0097 \mathrm{mg}$ iod/100gr minyak. Minyak atsiri kulit buah jeruk purut hasil destilasi uap memiliki bentuk cair, berwarna bening, dan berbau khas. Rendemen minyak atsiri kulit buah jeruk purut yang diperoleh sebesar $4,09 \%$.

\section{Analisis Minyak Atsiri Kulit Jeruk Purut}

Hasil analisis GC-MS pada minyak atsiri kulit jeruk purut memperlihatkan bahwa terdapat 7 senyawa dominan pada minyak atsiri kulit buah jeruk purut merupakan senyawa yang memiliki aktivitas sebagai repelan. Senyawa-senyawa tersebut adalah senyawa alpha pinene, D-Limonene, Linalool, Citronellal, Geraniol, dan Geranyl acetate. Senyawa-senyawa tersebut merupakan senyawa volatil yang termasuk kedalam golongan monoterpen yang berperan sabagai repelan. Senyawa aktif repelan dengan jumlah paling banyak dalam penelitian ini adalah alpha pinene dengan luas $18,988 \%$ dan citronellal dengan luas $15,444 \%$. Senyawa aktif citronellal dan geraniol sudah lama diteliti dan diduga mempunyai efek daya tolak terhadap nyamuk [5]. Terdeteksinya senyawasenyawa tersebut didalam minyak atsiri kulit buah jeruk purut memastikan bahwa minyak atsiri kulit buah jeruk purut dapat digunakan sebagai repelan.

Gambar 4 menunjukkan minyak atsiri kulit buah jeruk purut terdiri dari 42 puncak senyawa dengan beberapa puncak senyawa yang memiliki persen area relatif besar dan diduga dapat memberikan efek repelan terhadap nyamuk.
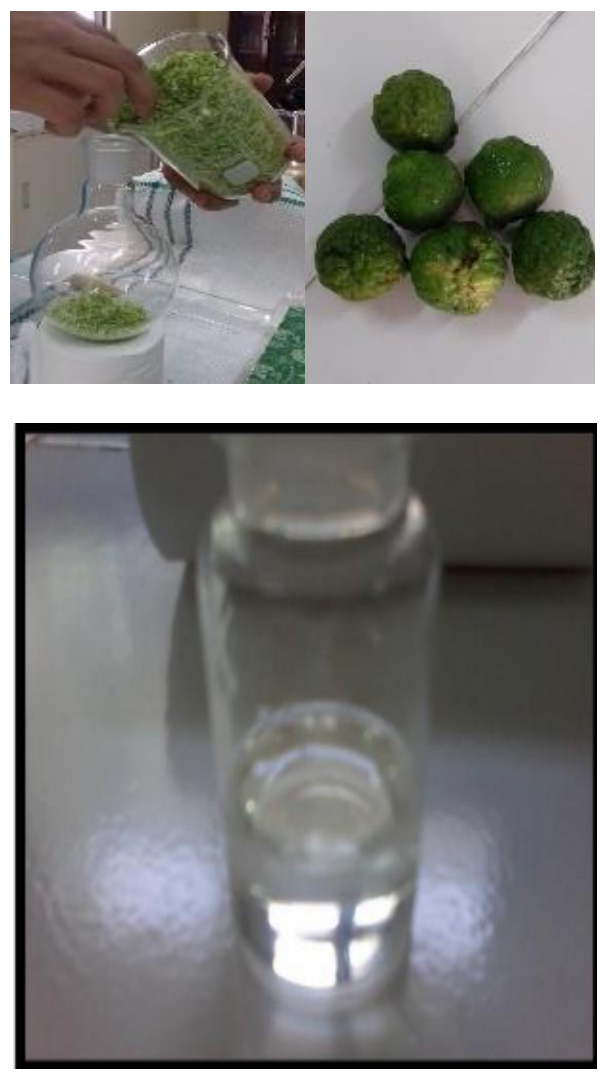

Gambar 3. Minyak atsiri kulit jeruk purut 


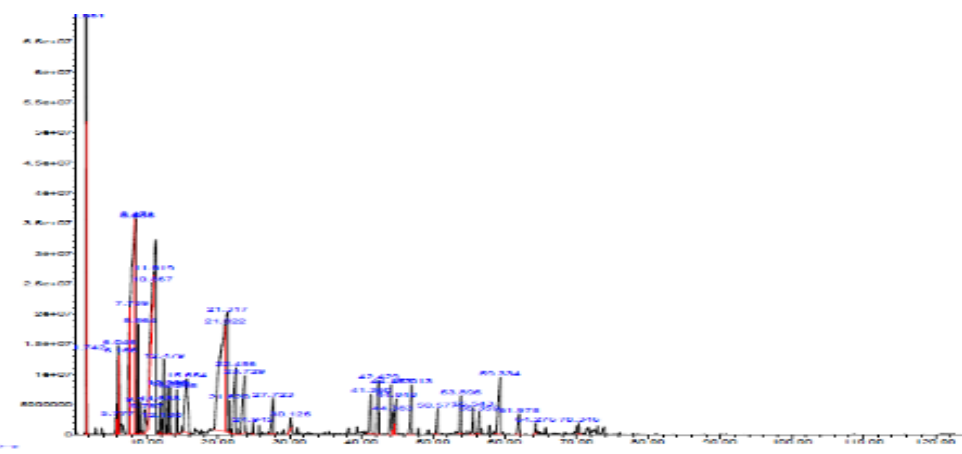

Gambarr 4. Hasil GC-MS minyak atsiri kulit buah jeruk purut

Tabel 1. Beberapa senyawa yang terkandung dalam minyak atsiri kulit buah jeruk purut berrdasarkan hasil

\begin{tabular}{ccccc}
\multicolumn{5}{c}{ GC-MS } \\
\hline Puncak & Waktu Retensi & SI & \% Area & Senyawa \\
\hline 8 & 8.469 & 91 & 18.988 & $\alpha$-pinene \\
10 & 8.586 & 91 & 2.996 & Beta-pinene \\
14 & 10.867 & 96 & 2.535 & D-Limonene \\
18 & 12.479 & 95 & 1.407 & $\gamma$ - Terpinene \\
22 & 15.654 & 96 & 3.326 & Linalool \\
23 & 21.022 & 95 & 15.444 & Citronellal \\
26 & 22.486 & 93 & 3.156 & Terpinen-4-ol \\
27 & 23.729 & 90 & 3.120 & Alpha-terpineol \\
30 & 30,126 & 93 & 0,24 & Geraniol \\
33 & 44.153 & 95 & 1.758 & Germacrene D \\
\hline
\end{tabular}

\section{Uji Organoleptik Lotion Repelan}

Hasil uji organoleptik pada ketiga formula lotion minyak ketapang diperoleh sifat fisik yang baik selama waktu penyimpanan. Uji organoleptik yang dilakukan terdiri dari warna, bau, dan homogenitas.

Warna, bau dan homogenitas dari ketiga formula memperlihatkan kesamaan sifat pada formula I, II dan III yang cenderung tidak berubah mulai dari pembuatan lotion pertama kali sampai 1 bulan penyimpanan. Warna lotion rata-rata disetiap sampel berwarna putih, berbau khas kulit jeruk dan memiliki homogenitas yang tetap stabil. pH lotion berkisar antara 6,7 sd 7,0 mulai dari awal pembuatan sampai waktu penyimpanan 1 bulan.

Tabel 2. Hasil Uji Organoleptik Lotion Repelan

\begin{tabular}{lllll}
\hline Formula & $\begin{array}{l}\text { Konsentrasi atsiri } \\
\text { kulit jeruk purut }\end{array}$ & Warna & Bau & Homogenitas \\
\hline I & $1 \%$ & putih & khas jeruk & homogen \\
II & $2 \%$ & putih & khas jeruk & homogen \\
III & $3 \%$ & putih & khas jeruk & homogen \\
\hline
\end{tabular}

\section{Uji Daya Repelan}

Hasil uji daya repelan pada berbagai penambahan variasi konsentrasi minyak atsiri dilakukan dengan cara memasukkan tangan yang telah dioles dengan lotion kedalam kurungan nyamuk. Pengujian dilakukan selama 5 jam, dengan masa pengamatan tiap jam selama 15 menit. Hasil uji daya repelan lotion dapat dilihat pada grafik dibawah ini.

Berdasarkan data hasil uji daya repelan pada berbagai variasi konsentrasi minyak atsiri menunjukkan bahwa daya repelan lotion berbanding lurus dengan konsentrasi minyak atsiri. Semakin tinggi konsentrasi minyak atsiri semak.; in tinggi pula daya repelan yang dimiliki lotion. Daya repelan lotion akan semakin berkurang seiring berjalannya waktu pengujian. Berdasarkan data diatas dapat diketahui bahwa lotion minyak ketapang dengan penambahan minyak atsiri kulit jeruk purut efektif menolak nyamuk dari jam ke-0 hingga jam ke-3 dan tidak terlalu efektif pada jam ke-4 hingga ke-5. Hal ini diduga karena sifat atsiri kulit jeruk purut yang sangat volatile menyebabkan daya proteksi semakin lama akan semakin berkurang. Namun daya proteksi hasil penelitian ini lebih tinggi dibanding hasil kajian [5] yang menyatakan bahwa daya proteksi bioinsektisida hanya mampu bertahan selama 2 jam saja. Sedangkan hasil penelitian dapat bertahan sampai 5 jam pertama walaupun terjadi penurunan yang signifikan pada jam ke-4 dan jam ke-5. Hal ini disebabkan oleh sediaan repelan dalam penelitian ini diaplikasikan dalam bentuk lotion, sehingga atsiri 
dapat bertahan lebih lama. Daya proteksi lotion hasil penelitian masih belum memenuhi standar yang ditetapkan oleh Komisi Pestisida Deptan dalam Metode Standar Pengujian Efikasi Pestisida, yaitu sebesar 90\% [9]. Standar ini diperuntukkan bagi repelan berbahan kimia seperti DEET yang lebih tahan lama dan tidak mudah rusak. Penurunan tingkat proteksi juga dapat dipengaruhi oleh konsentrasi senyawa yang terdapat dalam ekstrak.
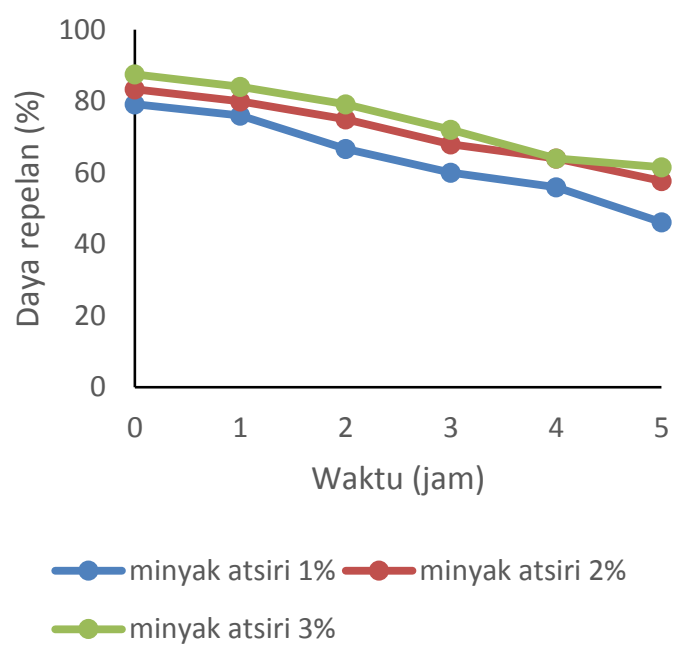

Gambar 5. Grafik pengaruh konsentrasi minyak atsiri kulit jeruk purut terhadap daya repelan lotion

\section{KESIMPULAN}

Hasil penelitian diperoleh kesimpulan bahwa komposisi senyawa kimia minyak ketapang tersusun atas asam lemak tak jenuh rantai panjang sehingga sangat berpotensi untuk dijadikan sebagai bahan baku utama lotion repelan. Lotion dengan berbagai variasi konsentrasi minyak atsiri kulit buah jeruk purut memiliki daya repelan yang sangat baik dengan persentase sebesar $87,5 \%$ dan mampu bertahan selama 3 jam. Setelah lebih dari 3 jam maka efektifitas daya repelan lotion akan berkurang, sehingga perlu diaplikasikan kembali. Krakterisasi lotion yang telah dilakukan sebagian besar karakter lotion memiliki sifat fisik yang baik terutama pada stabilitas dan $\mathrm{pH}$.

\section{UCAPAN TERIMAKASIH}

Ucapan terimakasih disampaikan kepada pihak Universitas Mataram atas pendanaan penelitian ini melalui sumber dana DIPA BLU skema Penelitian Dosen Pemula dengan No. Kontrak 27 8L |UNLS.LL /PP / 2020

\section{DAFTAR PUSTAKA}

[1] Hariani, P., Riyanti, F., \& Oktaviani, H. (2007). Analisis Mutu Minyak Biji Ketapang (Terminalia Catappa Linn.) Hasil Sokletasi. In Jurnal Penelitian Sains (Vol. 10, Issue 3).

[2] Husna, N., \& Purba, D. (2012). Efek Pelembab
Minyak Biji Bunga Matahari Dalam Sediaan Krim Tangan The Moisturizer Effect of Sunflower Seed Oil In Hand Cream Preparation. 1(1), 63-69.

[3] Janporn, S., Ho, C. T., Chavasit, V., Pan, M. H., Chittrakorn, S., Ruttarattanamongkol, K., \& Weerawatanakorn, M. (2015). Physicochemical properties of Terminalia catappa seed oil as a novel dietary lipid source. Journal of Food and Drug Analysis, 23(2), 201-209.

[4] Luzz stella nerio. (2010). repellent activity essential oil. February, 2021.

[5] Maia, M. F., \& Moore, S. J. (2011). Plantbased insect repellents : a review of their efficacy, development and testing PMD from lemon eucalyptus ( Corymbia citriodora ) extract. Malaria Journal, 10(Suppl 1), 1-15.

[6] Muhtadin, A. F., Wijaya, R., \& Prihatini, P. (2013). Pengambilan Minyak Atsiri dari Kulit Jeruk. Jurnal Teknik Pomits, 2(1), 98-101.

[7] Naseem, S., Munir, T., \& Faheem Malik, M. (2016). Mosquito management: A review. Journal of Entomology and Zoology Studies, 4(5), 73-79.

[8] Noverita, Jayuska, A., \& Alimuddin, A. H. (2014). Uji Aktivitas Antirayap Minyak Atsiri Kulit Jeruk Purut (Cytrus hystric D.C). Jurnal Kimia Khatulistiwa, 3(2), 19-22.

[9] Pertanian, D. (2007). standar pestisida. Departemen Pertanian, 2007-2009.

[10] Rahmaniar. (2013). Minyak biji ketapang(Terminalia catappa L.) sebagai bahan pelunak dalam pembuatan komponen karet. Dinamika Penelitian Industri, 24(1), 4959.

[11] Sofiana, L., \& Rahman, M. S. (2016). Perbedaan Status Kerentanan Nyamuk Aedes Aegypti Terhadap Malathion Di Kabupaten Bantul Yogyakarta. Jurnal Kesehatan Masyarakat, 11(2), 302.

[12] Sri Seno Handayani, Erin Ryantin Gunawan, Dedy Suhendra, M. dan I. M. A. (2020). PHYSICOCHEMICAL PROPERTIES OF CALOPHYLLUM OIL AS RAW MATERIAL OF TRANSPARENT SOLID SOAP. J. Pijar MIPA, 15(4), 411-415.

[13] Utomo, pramono putro. (n.d.). perbandingan daya proteksi lotion anti nyamuk dari beberapa jenis minyak atsiri tanaman pengusir nyamuk.

[14] Warsito, W., Noorhamdani, N., Sukardi, S., \& Dwi Susanti, R. (2017). MICROENCAPSULATION OF Cytrus hystrix OIL AND ITS ACTIVITY TEST AS AN ANTIMICROBIAL AGENT. Journal of Enviromental Engineering and Sustainable Technology, 4(2), 131-137. 